\title{
The Regulation of Pubertal Growth
}

\author{
Dennis M. Styne \\ Department of Pediatrics, University of California Davis Medical Center, Sacramento, Calif., USA
}

\section{Key Words}

Growth hormone - Insulin-like growth factor - Leptin • Nutrition · Gonadotropins · Gonadotropin-releasing hormone $\cdot$ Sex steroids $\cdot$ Puberty $\cdot$ Pubertal growth spurt

\begin{abstract}
To understand the regulation of pubertal growth, it is important to understand the present concept of the control of the onset of puberty, the change in secretion of sex steroids during puberty, and the effects of these various factors upon the production and action of growth hormone $(\mathrm{GH})$ and insulin-like growth factor (IGF). Nutrition plays a major role in this process because states of aberrant nutrition severely affect pubertal growth. In this article, all of these concepts will be discussed, including the effect of these factors upon bone growth during the increase in stature accomplished during puberty.
\end{abstract}

Copyright @ 2003 S. Karger AG, Basel

\section{Control of the Onset of Puberty}

The factors responsible for the control of the onset of puberty have been the subject of ongoing investigation for many decades and the answers are not yet complete. The human fetus and neonate have serum concentrations of gonadotropins and sex steroids that are equal or even greater than those of children with normal puberty (reviewed by Grumbach and Styne [1]). In the months and years after birth, a decrease in the activity of the hypothalamic-pituitary-gonadal axis occurs, known as the juvenile pause. Thus, in the primate, the central nervous system (CNS) restrains the onset of puberty until an appropriate age as the pituitary gland and the gonads are capable of response to the central messages at any age (albeit, some priming with the hypothalamic hormone may be required during the juvenile pause). Children with irradiation to the CNS or a tumour of the posterior pituitary gland (as well as other CNS conditions) may develop central precocious puberty at any age. Evidence from the rhesus monkey, a useful model of human endocrinology, indicates that in the female, the neurotransmitter gammaaminobutyric acid restrains puberty, while in the male there is evidence that neuropeptide Y (NPY) is the 'brake' on stimulation of pubertal development by the CNS [2]. At the time of puberty, with the decrease in restraint, excitatory neurotransmitters stimulate the release of gonadotropin-releasing hormone (GnRH) from the hypothalamus, which subsequently causes the appropriate endocrine changes during puberty. One of these neurotransmitters, paradoxically, appears to be NPY, which has inhibitory effects early in life and stimulatory effects at puberty, perhaps due to interactions with either of two different receptors [3].

\begin{tabular}{ll}
\hline KARGER & ( ) 2003 S. Karger AG, Basel \\
0301-0163/03/0607-0022\$19.50/0 \\
$\begin{array}{l}\text { Fax +4161306 12 34 } \\
\begin{array}{l}\text { E-Mail karger@karger.ch } \\
\text { www.karger.com }\end{array}\end{array}$ & $\begin{array}{l}\text { Accessible online at: } \\
\text { www.karger.com/hre }\end{array}$
\end{tabular}

Prof. D.M. Styne

Section of Pediatric Endocrinology

Department of Pediatrics, University of California Davis Medical Center

Sacramento, CA 95817 (USA)

Tel. +1916734 8223, Fax +1 916734 7070,E-Mail dmstyne@ucdavis.edu 


\section{Gonadotropins}

Gonadotropins are secreted from the anterior pituitary gland in a pulsatile manner in response to pulsatile secretion of GnRH from the hypothalamus. There is a diurnal rhythm that develops at puberty in which gonadotropins are released in peaks of greater amplitude at night than during the day and, therefore, serum gonadotropin values follow this same diurnal rhythm. Serum concentrations of sex steroids rise and fall in a similar rhythm but are delayed by a few hours. The advent of extremely sensitive assays for gonadotropins and sex steroids has allowed the detection of minute changes in serum concentrations of these hormones; with these new techniques it has become possible to demonstrate similar diurnal rhythms of gonadotropin secretion in pre-pubertal children as young as 5 years old, although the mass of hormone released per peak is much less at this age $[4,5]$. Thus, at puberty, there appears to be an increase in the amplitude of gonadotropin secretion, in the mass of gonadotropin secreted per pulse, and in mean luteinizing hormone levels but, at least in the most recent and longitudinal study, not in the frequency of gonadotropin pulses [6,7]. The rhesus monkey appears to undergo a change in frequency of the pulses of gonadotropin at puberty, but the sampling times and length of investigation differ from those in similar studies in the human, and these factors may account for some of the discrepancy in pattern between the species; alternatively, this might represent a biological difference between humans and non-human primates [2]. Although it has long been known that levels of sex steroids rise with pubertal development, it is only recently that ultrasensitive assays for oestradiol have become available to demonstrate subtle changes in patterns of secretion with development $[8,9]$. These supersensitive assays show higher oestradiol values in pre-pubertal girls than prepubertal boys and are able to demonstrate a difference in serum oestradiol in girls with premature thelarche compared with normal pre-pubertal girls [10].

\section{Growth Hormone}

The spontaneous secretion of growth hormone (GH) increases during puberty, with a close temporal relationship between this increase and the pubertal growth spurt [11]. Thus, serum GH rises in early puberty in girls and in late puberty in boys reflecting the differences in timing of the pubertal growth spurts between the sexes. While both boys and girls have increased serum GH concentrations, increased GH amplitude secreted per pulse, increased integrated $\mathrm{GH}$ concentrations over $24 \mathrm{~h}$ and increased GH production rate at puberty, boys demonstrate greater changes than girls. There is, however, no change in GH pulse (or burst) frequency at puberty. Furthermore, there is more disorganization (reported as entropy) in the pulse pattern in girls than in boys perhaps due to the effect of oestrogens on this phenomenon [12].

\section{Sex Steroids}

While testosterone administration increases GH secretion in boys [13] and oestrogen increases GH secretion in boys and girls [14] as well as those with Turner syndrome, administration of a non-aromatizable androgen such as dihydrotestosterone (DHT) or oxandrolone does not increase GH $[15,16]$. Furthermore, blockade of the effects of androgen (with flutamide) decreases GH secretion and blockade of the effects of oestrogen (with tamoxifen) [17] also decreases GH secretion. Testosterone and oestrogen, but not DHT, decrease orderliness of GH secretory patterns (increases entropy) [16]. Stimulated GH values after administration of insulin, arginine or many other secretagogues increase with pubertal development. Administration of sex steroids, usually oestrogen, to pre-pubertal children increases GH secretion to values similar to those seen during puberty. Furthermore, testosterone, but not DHT or other non-aromatizable androgens, increases GH secretion after secretagogues. All of this evidence points to the important role of oestrogen in pubertal growth and in pubertal GH secretion.

\section{GH-Binding Protein}

There is little change in GH-binding protein (GHBP) during puberty so that the state of GH binding per se is not an important factor in pubertal growth. As there is more GH and no change in GHBP levels, however, the free levels of $\mathrm{GH}$ do increase.

\section{Sex Steroids and GH Therapy}

The study of patients with various endocrine disorders teaches us many things about the regulation of the pubertal growth spurt. Patients with isolated GH deficiency (GHD) will increase their growth rate when they enter puberty, but the achieved growth will be less than during a 
normal pubertal growth spurt. Likewise, patients with normal GH secretion, but a hypogonadal condition that leads to absence of puberty, will not have a pubertal growth spurt. Those with coexistent GHD and hypogonadism will not have a pubertal growth spurt when GH alone is replaced. Thus, $\mathrm{GH}$ and sex steroids are necessary for a normal pubertal growth spurt. On the other hand, children with central precocious puberty and GHD, possibly caused by CNS irradiation, have an increased growth rate for age but the growth velocity is not as great as that seen in children with central precocious puberty with GH sufficiency [18]. If a $\mathrm{GnRH}$ agonist is given to suppress puberty, the growth rate will drop and may come close to ceasing altogether: this is due to the fact that there is no GH to stimulate growth and the sex steroids are also suppressed [19]. If GH is administered to such patients, the growth rate will approach closer to the normal rate for age, but the suppression of sex steroids might still not allow a completely normal growth rate. Thus, both sex steroids and $\mathrm{GH}$ are necessary for a pubertal growth spurt.

The question then arises: which sex steroid is most responsible for the pubertal growth spurt when added to GH? It was previously thought that testosterone exerts the greatest effect upon this process, but now it appears that oestradiol exerts the major effect [20]. This is demonstrated by the study of various disorders of androgen and oestrogen action. Most of the effects of testosterone appear to be due to the aromatization of testosterone to oestradiol by the enzyme aromatase. Serum oestradiol, as measured in the new ultrasensitive assay, rises in parallel with pubertal growth velocity normally in both boys and girls [21]. A sole adult male reported with oestrogen receptor deficiency [22] and other individuals with aromatase deficiency [23] did not, however, undergo a pubertal growth spurt. All of these patients had osteopenia, demonstrating the importance of oestrogen upon both the pubertal growth spurt and increasing bone density. In contrast, individuals with complete androgen insensitivity do have a pubertal growth spurt in spite of absence of any androgen effect although there is normal aromatase activity (to allow the androgen to be converted to oestrogen) as well as normal oestrogen receptors [24]. All of these classes of patients, however, have tall adult stature demonstrating the effect of prolonging the time of active growth because of delay in skeletal maturation and, therefore, delay of epiphyseal fusion. On the other hand, rare patients with familial aromatase excess have an increase in oestradiol production, which leads to advanced bone age, short stature caused by early epiphyseal fusion, and increased bone density resulting from the increased oestradiol effect [25].

\section{Insulin-Like Growth Factor I}

It is well established that levels of serum insulin-like growth factor I (IGF-I) rise during puberty and that this increase is correlated temporally with the pubertal growth spurt; thus, the rise occurs earlier in the process of puberty in girls and later in boys in a pattern reflecting the increasing GH secretion of puberty [26-29]. Levels of free IGF-I rise appreciably as levels of IGF-binding protein 3 and the acid-labile subunit increase with puberty, but not as strikingly as IGF-I itself rises [30, 31].

\section{Nutrition}

Nutrition exerts an important effect upon pubertal growth. When malnutrition occurs, growth, including pubertal growth, will suffer. In obesity in otherwise normal individuals, growth increases even though GH secretion and serum levels of GH decrease to lower than normal; this appears to result from an increase in GHBP, which reflects an apparent rise in $\mathrm{GH}$ receptors making the $\mathrm{GH}$ that is present all the more efficient [32]. Children may, however, still exhibit significant growth, even in the postoperative state after the removal of a craniopharyngioma or another pituitary tumour rendering them completely GH deficient; these patients are usually extremely obese $[33,34]$. Many factors are postulated to be the aetiology of such instances of growth without any detectable GH, including prolactin, IGF-I, IGF-II and increased insulin caused by the insulin resistance of the obese state [33]. When there is insulin resistance in obesity, the resistance is mainly in carbohydrate metabolism, not in amino acid physiology, so the growth-promoting actions of insulin may remain to stimulate growth. Furthermore, insulin may interact with the type 1 IGF receptor (that has a similar structure to the insulin receptor itself) and may stimulate growth in this way.

\section{Leptin}

Leptin is a factor that is regulated by nutrition and which also plays a role in puberty. Leptin is elevated in obese individuals and decreased in those with malnutrition as it is related to the mass of adipose tissue. Leptin was postulated to be the factor that linked the onset of puberty and the state of nutrition, but all studies to date, including longitudinal studies in both humans and rhesus monkeys, show that leptin rises in parallel with the 
increase in fat mass at puberty, but not before puberty begins; it cannot, therefore, serve as a trigger for pubertal development [35] (also reviewed by Grumbach and Styne [1]). Leptin is suppressed by androgens, so levels of leptin rise in both boys and girls in early puberty and continue to rise in girls; in boys, however, levels of leptin fall in later puberty when serum levels of androgens rise [36]. Female gymnasts or those with anorexia nervosa who have delayed or absent puberty have very low levels of serum leptin [37, 38]. Patients with leptin deficiency or leptin receptor defects may not go through puberty. A 10-yearold girl with leptin deficiency had a bone age of 13 years, but had no significant gonadotropin secretion. She was treated with recombinant derived human leptin and developed pulsatile luteinizing hormone secretion characteristic of puberty [39]. Together, these pieces of evidence suggest that leptin is permissive for pubertal development, but not the aetiological factor.
Can leptin be the link between obesity and increased growth? Recently, leptin receptors were found in cartilage tissue and the administration of leptin to cell cultures of such cartilage increased cartilage growth and even stimulated the appearance of IGF-I receptors [40]. Thus, it is possible that leptin may play a role in stimulating bone growth directly.

\section{Conclusion}

The remarkable growth seen during pubertal development is orchestrated by a wide variety of influences. Nutrition and the endocrine effects of GH and oestrogen appear to be the main factors in the process.

\section{References}

1 Grumbach MM, Styne DM: Puberty, ontogeny, neuroendocrinology, physiology, and disorders; in Larsen PR, Kronenberg HM, Melmed S, Plonsky KS (eds): Williams Textbook of Endocrinology. ed 10. Philadelphia, W.B. Saunders Company, 2002, pp 1115-1286.

2 Plant TM: Neurobiological bases underlying the control of the onset of puberty in the rhesus monkey: a representative higher primate. Front Neuroendocrinol 2001;22:107-139.

3 Terasawa E, Fernandez DL: Neurobiological mechanisms of the onset of puberty in primates. Endocr Rev 2001;22:111-151.

4 Mitamura R, Yano K, Suzuki N, Ito Y, Makita Y, Okuno A: Diurnal rhythms of luteinizing hormone, follicle-stimulating hormone, and testosterone secretion before the onset of male puberty. J Clin Endocrinol Metab 1999;84:29_ 37.

5 Mitamura R, Yano K, Suzuki N, Ito Y, Makita Y, Okuno A: Diurnal rhythms of luteinizing hormone, follicle-stimulating hormone, and testosterone secretion before the onset of male puberty. J Clin Endocrinol Metab 1999;84:2937.

6 Dunkel L, Alfthan H, Stenman UH, Tapanainen P, Perheentupa J: Pulsatile secretion of LH and FSH in prepubertal and early pubertal boys revealed by ultrasensitive time-resolved immunofluorometric assays. Pediatr Res 1990; 27:215-219.

7 Dunkel L, Alfthan H, Stenman UH, Selstam G, Rosberg S, Albertsson-Wikland K: Developmental changes in 24-hour profiles of luteinizing hormone and follicle-stimulating hormone from prepuberty to midstages of puberty in boys. J Clin Endocrinol Metab 1992;74:890897.
8 Klein KO, Baron J, Colli MJ, McDonnell DP, Cutler GBJ: Estrogen levels in childhood determined by an ultrasensitive recombinant cell bioassay. J Clin Invest 1994;94:2475-2480.

9 Klein KO, Mericq V, Brown-Dawson JM, Larmore KA, Cabezas P, Cortinez A: Estrogen levels in girls with premature thelarche compared with normal prepubertal girls as determined by an ultrasensitive recombinant cell bioassay. J Pediatr 1999;134:190-192.

10 Klein KO, Martha PMJ, Blizzard RM, Herbst T, Rogol AD: A longitudinal assessment of hormonal and physical alterations during normal puberty in boys. II. Estrogen levels as determined by an ultrasensitive bioassay. J Clin Endocrinol Metab 1996;81:3203-3207.

11 Mauras N, Blizzard RM, Link K, Johnson ML, Rogol AD, Veldhuis JD: Augmentation of growth hormone secretion during puberty: evidence for a pulse amplitude-modulated phenomenon. J Clin Endocrinol Metab 1987;64: 596-601.

12 Veldhuis JD, Roemmich JN, Rogol AD: Gender and sexual maturation-dependent contrasts in the neuroregulation of growth hormone secretion in prepubertal and late adolescent males and females - a general clinical research center-based study. J Clin Endocrinol Metab 2000;85:2385-2394.

13 Giustina A, Scalvini T, Tassi C, Desenzani P, Poiesi C, Wehrenberg WB, Rogol AD, Veldhuis JD: Maturation of the regulation of growth hormone secretion in young males with hypogonadotropic hypogonadism pharmacologically exposed to progressive increments in serum testosterone. J Clin Endocrinol Metab 1997;82:1210-1219.
14 Marin G, Domene HM, Barnes KM, Blackwell BJ, Cassorla FG, Cutler GBJ: The effects of estrogen priming and puberty on the growth hormone response to standardized treadmill exercise and arginine-insulin in normal girls and boys. J Clin Endocrinol Metab 1994;79: 537-541.

15 Keenan BS, Richards GE, Ponder SW, Dallas JS, Nagamani M, Smith ER: Androgen-stimulated pubertal growth: the effects of testosterone and dihydrotestosterone on growth hormone and insulin-like growth factor-I in the treatment of short stature and delayed puberty. J Clin Endocrinol Metab 1993;76:996-1001.

16 Veldhuis JD, Metzger DL, Martha PM Jr, Mauras N, Kerrigan JR, Keenan B, Rogol AD, Pincus SM: Estrogen and testosterone, but not a nonaromatizable androgen, direct network integration of the hypothalamo-somatotrope (growth hormone)-insulin-like growth factor I axis in the human: evidence from pubertal pathophysiology and sex-steroid hormone replacement. J Clin Endocrinol Metab 1997;82: 3414-3420.

17 Metzger DL, Kerrigan JR: Estrogen receptor blockade with tamoxifen diminishes growth hormone secretion in boys: evidence for a stimulatory role of endogenous estrogens during male adolescence. J Clin Endocrinol Metab 1994;79:513-518.

18 Attie KM, Ramirez NR, Conte FA, Kaplan SL, Grumbach MM: The pubertal growth spurt in eight patients with true precocious puberty and growth hormone deficiency: evidence for a direct role of sex steroids. J Clin Endocrinol Metab 1990;71:975-983. 
19 Cara JF, Kreiter ML, Rosenfield RL: Height prognosis of children with true precocious puberty and growth hormone deficiency: effect of combination therapy with gonadotropin releasing hormone agonist and growth hormone. $\mathrm{J}$ Pediatr 1992;120:709-715.

20 Grumbach MM: Estrogen, bone, growth, and sex: a sea change in conventional wisdom. J Pediatr Endocrinol Metab 2000;13(suppl 6): 1439-1455.

21 Klein KO, Martha PMJ, Blizzard RM, Herbst T, Rogol AD: A longitudinal assessment of hormonal and physical alterations during normal puberty in boys. II. Estrogen levels as determined by an ultrasensitive bioassay. J Clin Endocrinol Metab 1996;81:3203-3207.

22 Smith EP, Boyd J, Frank GR, Takahashi H, Cohen RM, Specker B, Williams TC, Lubahn DB, Korach KS: Estrogen resistance caused by a mutation by the estrogen-receptor in a man. N Engl J Med 1994;331:1056-1061.

23 Conte FA, Grumbach MM, Ito Y, Fisher CR, Simpson ER: A syndrome of female pseudohermaphrodism, hypergonadotropic hypogonadism and multicystic ovaries associated with missence mutations in the gene encoding aromatase (P450 arom). J Clin Endocrinol Metab 1994; 78:1287-1292.

24 Zachmann M, Prader A, Sobel EH, Crigler JF Jr, Ritzen EM, Atares M, Ferrandez A: Pubertal growth in patients with androgen insensitivity: indirect evidence for the importance of estrogens in pubertal growth of girls. J Pediatr 1986;108:694-697.

25 Stratakis CA, Vottero A, Brodie A, Kirschner LS, DeAtkine D, Lu Q, Yue W, Mitsiades CS Flor AW, Chrousos GP: The aromatase excess syndrome is associated with feminization of both sexes and autosomal dominant transmission of aberrant P450 aromatase gene transcription. J Clin Endocrinol Metab 1998;83: 1348-1357.
26 Lofqvist C, Andersson E, Gelander L, Rosberg S, Blum WF, Albertsson-Wikland K: Reference values for IGF-I throughout childhood and adolescence: a model that accounts simultaneously for the effect of gender, age, and puberty. J Clin Endocrinol Metab 2001;86:5870-5876.

27 Bala RM, Lopatka J, Leung A: Serum immunoreactive somatomedin levels in normal adults, pregnant women at term, children at various ages, and children with constitutionally delayed growth. J Clin Endocrinol Metab 1981; 52:508-512.

28 Luna AM, Wilson DM, Wibbelsman CJ, Brown RC, Nagashima RJ, Hintz RL, Rosenfeld RG: Somatomedins in adolescence: a cross-sectional study of the effect of puberty on plasma insulin-like growth factor I and II levels. J Clin Endocrinol Metab 1983;57:268271.

29 Harris DA, Van Vliet G, Egli CA, Grumbach MM, Kaplan SL, Styne DM, Vainsel M: Somatomedin-C in normal puberty and in true precocious puberty before and after treatment with a potent luteinizing hormone-releasing hormone agonist. J Clin Endocrinol Metab 1985;61:152-159.

30 Kawai N, Kanzaki S, Takano-Watou S, Tada C, Yamanaka Y, Miyata T, Oka M, Seino Y: Serum free insulin-like growth factor I (IGF-I), total IGF-I, and IGF-binding protein- 3 concentrations in normal children and children with growth hormone deficiency. J Clin Endocrinol Metab 1999;84:82-89.

31 Yamada M, Hasegawa T, Hasegawa Y: Increase in free insulin-like growth factor-I levels in precocious and normal puberty. Endocr $\mathrm{J}$ 1998;45:407-412.

32 Kratzsch J, Dehmel B, Pulzer F, Keller E, Englaro P, Blum WF, Wabitsch M: Increased serum GHBP levels in obese pubertal children and adolescents: relationship to body composition, leptin and indicators of metabolic disturbances. Int J Obes Relat Metab Disord 1997; $21: 1130-1136$
33 Geffner ME: The growth without growth hormone syndrome. Endocrinol Metab Clin North Am 1996;25:649-663.

34 De Vile CJ, Grant DB, Hayward RD: Obesity in childhood craniopharyngioma: relation to post-operative hypothalamic damage shown by magnetic resonance imaging. J Clin Endocrinol Metab 1996;81:2734-2737.

35 Ahmed ML, Ong KK, Morrell DJ, Cox L, Drayer N, Perry L, Preece MA, Dunger DB: Longitudinal study of leptin concentrations during puberty: sex differences and relationship to changes in body composition. J Clin Endocrinol Metab 1999;84:899-905.

36 Blum WF, Englaro P, Hanitsch S, Juul A, Hertel NT, Muller J, Skakkebaek NE, Heiman ML, Birkett M, Attanasio AM, Kiess W, Rascher W: Plasma leptin levels in healthy children and adolescents: dependence on body mass index, body fat mass, gender, pubertal stage, and testosterone. J Clin Endocrinol Metab 1997;82: 2904-2410.

37 Matejek N, Weimann E, Witzel C, Molenkamp G, Schwidergall S, Bohles H: Hypoleptinaemia in patients with anorexia nervosa and in elite gymnasts with anorexia athletica. Int J Sports Med 1999;20:451-456.

38 Weimann E, Blum WF, Witzel C, Schwidergall S, Bohles HJ: Hypoleptinemia in female and male elite gymnasts. Eur J Clin Invest 1999;29: 853-860.

39 Farooqi IS, Jebb SA, Langmack G, Lawrence E, Cheetham $\mathrm{CH}$, Prentice AM, Hughes IA, McCamish MA, O'Rahilly S: Brief report: effects of recombinant leptin therapy in a child with congenital leptin deficiency. N Engl J Med 1999;341:879-884.

40 Maor G, Rochwerger M, Segev Y, Phillip M: Leptin acts as a growth factor on the chondrocytes of skeletal growth centers. J Bone Miner Res 2002; 17:1034-1043. 